\title{
Diversity, vertical structure and floristic relationships of vascular epiphytes in an urban remnant of the Brazilian Atlantic Forest
}

\author{
Lucas Deziderio Santana ${ }^{1}$, Samyra Gomes Furtado ${ }^{1}$, Camila Nardy ${ }^{1}$, \\ Felipe Silveira Leite ${ }^{2}$ and Luiz Menini Neto ${ }^{3,4}$
}

Received: 21.6.2016; accepted: 23.01.2017

\begin{abstract}
Diversity, vertical structure and floristic relationships of vascular epiphytes in an urban remnant of the Brazilian Atlantic Forest). This study was conducted in a fragment of montane seasonal semi-deciduous forest (Minas Gerais State) with a history of anthropogenic disturbance. Our goals were to characterise the composition, structure and floristic diversity of vascular epiphytes and to investigate the floristic similarities of the community with other areas of urban seasonal forests in Brazil. We sampled 61 phorophytes with 47 epiphytic species. The richest families were Bromeliaceae (seven) and Polypodiaceae (seven). The most common ecological category was accidental holoepiphytes with 21 species an unprecedented result for the Neotropical region. The Shannon index was 2.95 and the Pielou evenness index 0.77, showing a relatively high diversity with a few dominant species and numerous rare species. Similarity analyses showed a longitudinal gradient and strong influence of the distance from the ocean on floristic relationships as well as influence of dense ombrophilous forests on the composition of the vascular epiphytes of the surveyed area.

Keywords: accidental holoepiphytes, biodiversity hotspot, multivariate analyses, taxonomic diversity, urban forest
\end{abstract}

RESUMO - (Diversidade, estrutura vertical e relações florísticas de epífitas vasculares em um remanescente urbano da Floresta Atlântica brasileira). Este estudo foi realizado em um fragmento de floresta estacional semidecidual montana (Minas Gerais) com histórico de perturbação antrópica. Os objetivos foram caracterizar a composição, estrutura e diversidade florística das epífitas vasculares e investigar a similaridade florística da comunidade com outras áreas de florestas estacionais urbanas no Brasil. Foram amostrados 61 forófitos e registradas 47 espécies de epífitas. As famílias mais ricas foram Bromeliaceae (sete) e Polypodiaceae (sete). A categoria ecológica mais comum foi a de holoepífitas acidentais com 21 espécies - um resultado inédito na Região Neotropical. O índice de Shannon foi 2,95 e o índice de uniformidade de Pielou foi 0,77, mostrando diversidade relativamente alta com certa dominância de poucas espécies, enquanto as espécies raras foram numerosas. Análises de similaridade mostraram gradiente longitudinal e forte influência da distância do oceano sobre as relações florísticas, assim como influência das florestas ombrófilas densas sobre a composição das epífitas vasculares na área estudada.

Palavras-chave: análises multivariadas, diversidade taxonômica, floresta urbana, holoepífitas acidentais, "hotspot" de biodiversidade

\section{Introduction}

Tropical forests are characterised by warm and humid climates with little variation of temperature and marked stratification (Ricklefs 2011). In terms of epiphytes, they are the richest forests in the world, amassing more than $60 \%$ of all species (Biedinger \& Fischer 1996). However, due to population growth and the need for territorial expansion, these forests are heavily fragmented, reinforcing the importance of maintaining remnants in urban areas. Such urban forests are considered important agents of the local microclimate "by reducing the pollution and maintaining the temperature", and they present great aesthetical value and importance to human welfare (Bolund \& Hunhammar 1999, Bonametti 2003, Mckinney 2008). Urbanisation results in disturbance, and changes in the environmental conditions are evident and conducive to biotic modifications, for instance, in species composition (Mckinney 2008).

1. Universidade Federal de Juiz de Fora, Programa de Pós-graduação em Ecologia, 36036-930 Juiz de Fora, MG, Brasil

2. Universidade Federal de Juiz de Fora, Curso de Ciências Biológicas, 36036-930 Juiz de Fora, MG, Brasil

3. Centro de Ensino Superior de Juiz de Fora, Rua Luz Interior 345, Estrela Sul, 36030-776 Juiz de Fora, MG, Brasil

4. Corresponding author: menini.neto@gmail.com 
However, few scientific studies have concentrated on urban environments (Marris 2009).

Vascular epiphytes are plants not connected to the soil or connected during only one life stage, using the phorophytes as support without parasitizing them through haustoria (Madison 1977). This synusia has great ecological importance, providing resources, such as fruits, nectar, pollen and water to the fauna and microhabitats to several animal groups (Benzing 1990). Vascular epiphytes are represented by about 29,000 species, or $10 \%$ of all vascular flora, distributed in 876 genera and 84 families (Zotz 2013). Globally seen, the Orchidaceae, Araceae and Bromeliaceae are the richest families (Gentry \& Dodson 1987, Zotz 2013). The Brazilian Atlantic forest, an important global biodiversity hotspot (Myers et al. 2000), exhibits similar configuration of the richest epiphyte families, with about 2,256 species, mainly distributed in the Orchidaceae (46.5\%), Bromeliaceae (26.2\%), Polypodiaceae (4.3\%) and Araceae (4.2\%) (Freitas et al. 2016).

Knowledge about this synusia in Brazilian urban environments must still be considered as scarce, although a growing number of studies have been published in the last ten years, but concentrated in Brazil's South Region (e.g., Dislich \& Mantovani 1998, Dittrich et al. 1999, Gonçalves \& Waechter 2003, Borgo et al. 2002, Fabricante et al. 2006, Hefler \& Faustioni 2004, Dettke et al. 2008, Geraldino et al. 2010, Oliveira et al. 2013, Alves et al. 2014, Becker et al. 2015, Furtado \& Menini Neto 2015). This reflect our knowledge about the epiphytic flora as a whole, since the majority of studies have also been conducted in South Brazil (Kersten 2010). Since a reduction of the anthropogenic pressure on the environment is rather unlikely in the near future (Hietz 1999), the composition of epiphytes needs to be investigated in different environments, such as isolated trees, plantations and urban forests, in order to develop effective conservation strategies.

Thus, the present study was conducted in order to expand our knowledge about the epiphytic flora in urban environments in Brazil's Southeastern Region. The municipality of Juiz de Fora, located southeast of Minas Gerais, represents a suitable area to perform such a study. It is well connected to the other regions of the Serra da Mantiqueira and integrates the Corredor Sudeste (southeastern corridor) of the Atlantic Forest, which characterises it as a region of "very high" biological importance (Drummond et al. 2005).
This study aimed to contribute to our knowledge about epiphytic synusia in an urban forest through characterisation of the composition, structure and floristic diversity of vascular epiphytes in a remnant of a seasonal semi-deciduous forest in the Atlantic domain. In addition, we investigated the floristic similarity of this community with other areas composed of urban seasonal forests in the same phytogeographic domain. Based on data available in the literature, we tested the following hypotheses: 1) the study area has low richness and diversity of epiphytic species, suggesting that urban areas tend to be more susceptible to human impacts (McKinney 2006, 2008); 2) the specific and generic composition and the proportion of ecological categories tend to be similar between urban areas as some species are more tolerant to anthropogenic stresses (Barthlott et al. 2001, Bermudez et al. 2009); 3) Because humidity is an important factor for the establishment of epiphytes (Johansson 1974, Benzing 1990), the areas closer to the ocean are clustered by separating those that are farther away from the ocean.

\section{Materials and methods}

Study area - The study was conducted at the edge of an urban fragment of secondary montane seasonal semi-deciduous forest (SSF) (Veloso et al. 1991) in altitudes ranging from $670-750$ m.s.m. in an area of about 87 ha belonging to the Botanical Garden of the Federal University of Juiz de Fora in the municipality of Juiz de Fora, Zona da Mata of Minas Gerais $\left(21^{\circ} 44^{\prime} \mathrm{S}, 43^{\circ} 22^{\prime} \mathrm{W}\right)$ (figure 1). This fragment is close to the environmental protection area Mata do Krambeck (MK) which encompasses about 300 ha and is composed of continuous secondary forest on a former coffee crop plantation. Regeneration processes have been taking place for the last 70 years, although the area is frequently under strong anthropogenic pressure from the surrounding municipalities, such as selective logging and introduction of exotic species (Fonseca \& Carvalho 2012).

According to the Köppen classification, the climate in the region is Cwa, with dry and cold winters and rainy and warm summers. Mean annual rainfall is about $1,500 \mathrm{~mm}$, with higher rates during January ( 300 mm) (PMJF 2014). Mean annual temperature is about $18.9^{\circ} \mathrm{C}$, the hottest and coldest months are February $\left(21.7^{\circ} \mathrm{C}\right)$ and July $\left(16.1^{\circ} \mathrm{C}\right)$, respectively (PJF 2014). 


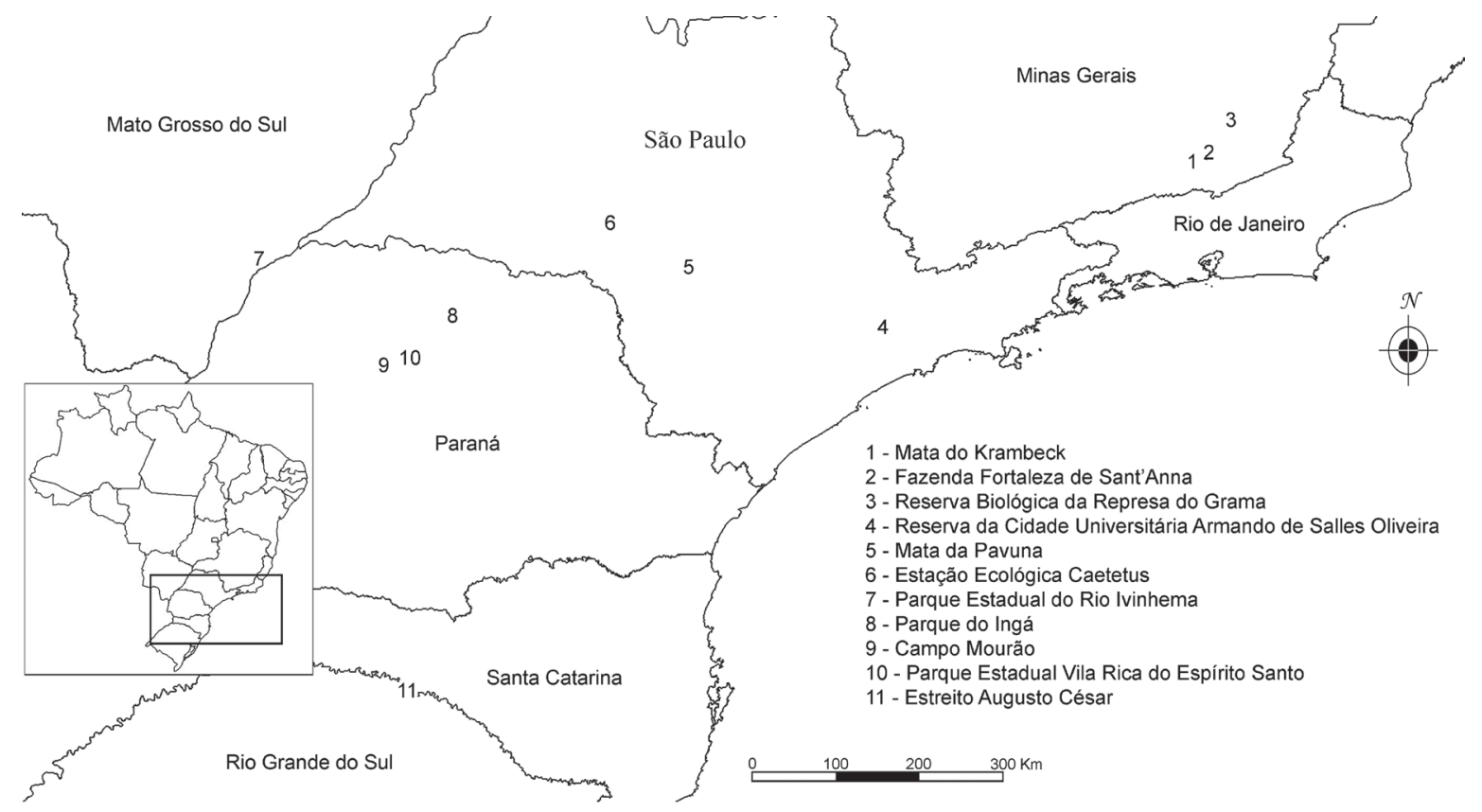

Figure 1. Location of the Mata do Krambeck and the other 10 areas used in multivariate analyses.

Field and laboratory work - Field surveys were conducted from August to November 2013. We analysed the 61 largest phorophytes around a lake and marsh in an area of about $31,000 \mathrm{~m}^{2}$. The phorophytes belonged to several species, both native and cultivated (exotic or native) (table 1). Plants were collected and herborised using common methodologies and were identified through analysis of previous collections deposited in the CESJ Herbarium of the Federal University of Juiz de Fora (acronym according to Thiers 2016), specialised literature and consultation with specialists.

The phorophytes were analysed using a methodology adapted from Johansson (1974) and the trees were divided into four strata: A) trunk base: from the base of the bole up to $50 \mathrm{~cm}$ from the soil; B) trunk top: from $50 \mathrm{~cm}$ up to the first ramification; C) internal crown: the first ramification of the crown; and D) external crown: the remaining part of the crown.

The epiphytes were classified into four ecological categories according to the relationship with the phorophyte, as proposed by Benzing (1990): characteristic holoepiphytes (CHLs), facultative holoepiphytes (FHLs), accidental holoepiphytes (AHLs), and hemiepiphytes (HEMs).

Geographic distribution of the species was obtained by consulting the BFG's database (2015) and five patterns of distribution were observed: 1 ) endemic to the Atlantic forest; 2) occurring in the Cerrado and the Atlantic forest; 3) disjunct between the Amazon and the Atlantic forest; 4) occurring in the three or more phytogeographic domains (wide distribution); and 5) exotic, invasive and/or cultivated.

Statistical analyses - The calculated parameters are relative and absolute frequencies (conducted in Microsoft Office Excel 2007), Shannon diversity index $\left(H^{\prime}\right)$ and Pielou evenness $(J)$ for the total and for each stratum [(in Past v. 3 (Hammer et al. 2001)]. In addition, we calculated indices of taxonomic diversity $(\Delta)$, taxonomic distinction $\left(\Delta^{*}\right)$, average taxonomic distinction $\left(\Delta^{+}\right)$and variation in taxonomic distinction $\left(\Lambda^{+}\right)$for each stratum according to Clarke \& Warwick (1998, 2001), using the R package ( $R$ Core Team 2014).

We constructed a matrix of presence (1) and absence (0) with 238 species of vascular epiphytes from 11 areas of seasonal forests of the Atlantic forest (figure 1, table 2). The matrix was used in cluster and ordination analyses, respectively, using UPGMA (Unweighted Pair Group Method with Arithmetic Mean) and PCoA (Principal Coordinate Analysis), both using the Jaccard index. Infraspecific, unidentified and accidental epiphytic taxa (given their occurrence was stochastic) were removed from multivariate analyses [conducted in Past v.3 (Hammer et al. 2001)].

A Mantel test, conducted in Past v.3 (Hammer et al. 2001), was applied to evaluate the correlation between floristic similarity (Jaccard index) and the geographic distances of the areas. 
Table 1. Phorophytic species, origin and respective occurrences of epiphytic species.

\begin{tabular}{lccccc}
\hline Species & Families & Origin & NP & $\%$ P & NES \\
\hline Piptadenia gonoacantha (Mart.) J.F. Macbr. & Fabaceae & native & 13 & 21,3 & 19 \\
Cedrela fissilis Vell. & Meliaceae & native & 11 & 18,0 & 18 \\
Eryobotria japonica (Thunb.) Lindl. & Rosaceae & exotic & 8 & 13,1 & 11 \\
Unidentified & - & - & 5 & 8,2 & 22 \\
Ceiba speciosa (A.St.-Hil.) Ravenna & Malvaceae & native & 5 & 8,2 & 15 \\
Fabaceae (unidentified) & Fabaceae & - & 5 & 8,2 & 16 \\
Tibouchina granulosa (Desr.) Cogn. & Melastomataceae & native & 4 & 6,6 & 6 \\
Mangifera indica L. & Anacardiaceae & exotic & 1 & 1,6 & 5 \\
Syzygium cumini (L.) Skeels & Myrtaceae & exotic & 1 & 1,6 & 4 \\
Arecaceae (unidentified) & Arecaceae & - & 1 & 1,6 & 3 \\
Cupania emarginata Cambess. & Sapindaceae & native & 1 & 1,6 & 3 \\
Euterpe edulis Mart. & Arecaceae & native & 1 & 1,6 & 3 \\
Sapindaceae (unidentified) & Sapindaceae & - & 1 & 1,6 & 3 \\
Araucaria angustifolia (Bertol.) Kuntze & Araucariaceae & native & 1 & 1,6 & 2 \\
Alchornea triplinervia (Spreng.) Müll.Arg. & Euphorbiaceae & native & 1 & 1,6 & 1 \\
Syagrus sp. & Arecaceae & - & 1 & 1,6 & 1 \\
Syzygium jambos Duthie & Myrtaceae & exotic & 1 & 1,6 & 1 \\
\hline
\end{tabular}

NP: number of phorophytic individuals; \% P: percentage of total phorophytic individuals; NES: number of epiphytic species occurring upon the phorophytic species.

\section{Results}

We found 47 species belonging to 33 genera and 17 families (table 3). The richest families were Bromeliaceae and Polypodiaceae (seven species each), followed by Orchidaceae (five species) and Araceae (four species), which represented 23 species (about 48\%) found in the study area. Tillandsia (Bromeliaceae) was the richest genus with four species, followed by Pleopeltis (Polypodiaceae) with three species. The majority of genera (26) were represented by only one species.

Geographic distribution of the identified species showed a predominance of widely distributed species occurring in two or more phytogeographic domains in Brazil (25 species, of which seven were restricted to the Cerrado and the Atlantic forest), while only seven species were endemic to the Atlantic forest and another seven were exotic (both cultivated and invasive, table 3).

The most common ecological category was the AHLs with 21 species, followed by the CHLs (19 species), HEMs (five species) and FHLs (two species) (table 3).

The Shannon index value $\left(H^{\prime}\right)$ was 2.95 and the Pielou evenness index $\left(J^{\prime}\right) 0.77$. Both indices were compared with those obtained in the SSF areas in southern and southeastern regions of Brazil (table 4).

Six species must be highlighted due to their occurrence on more than 10 phorophytes (figure 2). Table 5 shows the common occurrence of Tillandsia, Microgramma and Pleopeltis species in comparison with more frequent species found in studies conducted in SSF areas in the south and southeastern regions of Brazil.

We observed 432 occurrences in the strata distributed as follows: 49 in the trunk base, 101 in the trunk top, 115 in the internal crown and 167 in the external crown. Thus, the tree crown accounted for $65 \%$ of the records. The values of $H^{\prime}, J, \Delta, \Delta^{*}, \Delta^{+}$ and $\Lambda^{+}$for each stratum are presented in table 6 .

The presence and absence matrix showed that 11 species occurred in more than half of the areas: Billbergia zebrina, Tillandsia recurvata, $T$. stricta and T. tricholepis (Bromeliaceae); Epiphyllum phyllanthus, Lepismium cruciforme and Rhipsalis cereuscula (Cactaceae); Miltonia flavescens, Oncidium pumilum and Polystachya estrellensis (Orchidaceae); and Microgramma squamulosa (Polypodiaceae). Of these, only four were not recorded in the present study: L. cruciforme, M. Alavescens, O. pumilum and $R$. cereuscula. We must highlight five species that were found in eight or more areas: E. phyllanthus, 

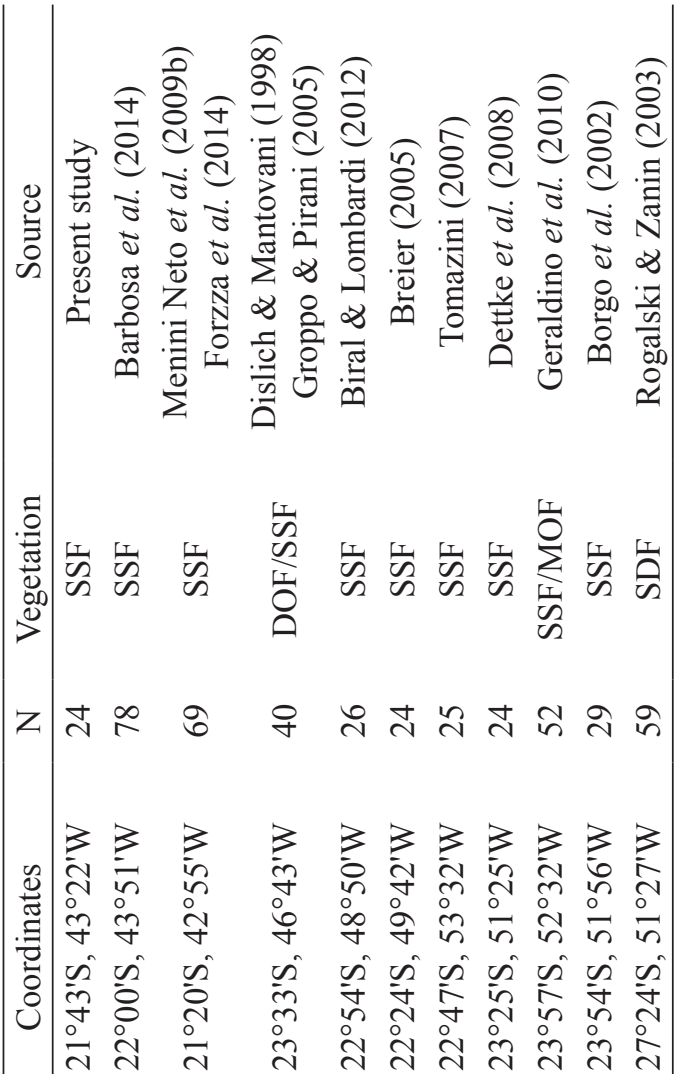
ह

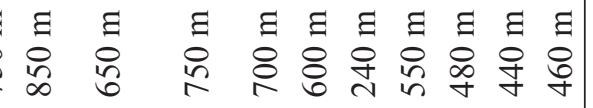

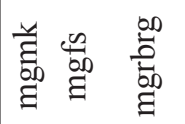

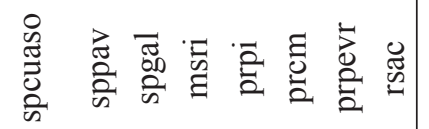

L. cruciforme, M. squamulosa, P. estrellensis and $T$. recurvata.

Cluster analysis obtained a high cophenetic coefficient (0.91), exhibiting a good fit between the dendrogram and the presence and absence matrix. The dendrogram (figure 3 ) showed the formation of two groups, A and B. Group A was composed of the majority of areas located in Minas Gerais, except "spcuaso", which is located in the State of São Paulo, and all four areas closer to the ocean compared to the areas of group B. The results of the PCoA (figure 4) reinforced the tendency of segregation between areas closer to the littoral (at the right hand side of the graphic, being the same group A of the dendrogram) from the inland areas (at the left hand side, which integrated group B of the dendrogram). The results of the Mantel test showed a weak non-significant, positive correlation between geographic distance and floristic similarity of the areas $(R=0.139 ; p=0.206)$.

\section{Discussion}

Richness and geographic distribution - The most species-rich families in the MK (Bromeliaceae, Polypodiaceae, Araceae and Orchidaceae) share a common, similar status in several floristic and/ or ecological surveys conducted on different forest physiognomies, both in the Atlantic forest (Waechter 1992, Dittrich et al. 1999, Kersten \& Silva 2001, Kersten et al. 2009, Menini Neto et al. 2009a, Bianchi et al. 2012, Alves \& Menini Neto 2014, Barbosa et al. 2014) and the Neotropical region (Catling \& Lefkovitch 1989, Hietz \& Hietz-Seifert 1995, Arévalo $\&$ Betancur 2004). These families are also the richest ones in terms of vascular epiphytes (Gentry \& Dodson 1987, Benzing 1990, Zotz 2013).

However, the observed configuration in the Neotropical region, in which Orchidaceae is the richest family, often followed by Bromeliaceae (Linares 1999, Bussmann 2001, Rogalski \& Zanin 2003, Arévalo \& Betancur 2004, Giongo \& Waechter 2004, Cervi \& Borgo 2007, Menini Neto et al. 2009b, Ceja-Romero et al. 2010, Alves \& Menini Neto 2014, Barbosa et al. 2014), is different in this study since Bromeliaceae and Polypodiaceae shared the first position (with seven species each) and Orchidaceae exhibited only five species.

Such results could be related to the anthropogenic disturbance in the studied area, since in urban environments of the Brazilian Atlantic forest, Orchidaceae often exhibit fewer species than 


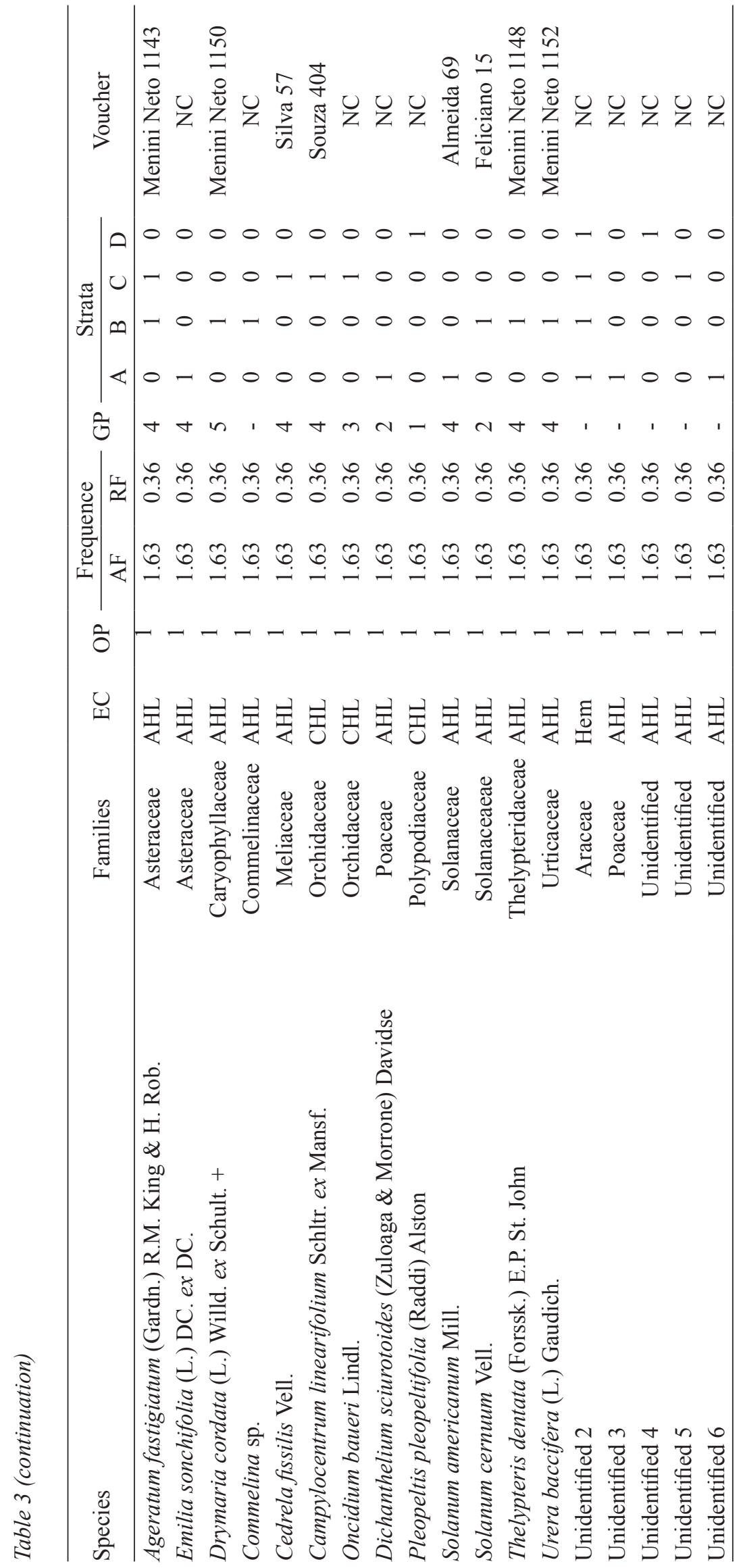

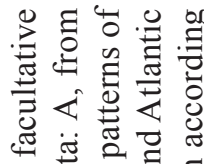

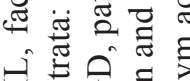

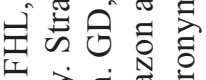

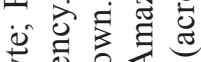
至 すั 율 可 응. 星氛这 ॠञّ 눈 ठृ

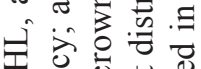
《 0 ⿹

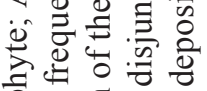
言䒕。的 ठ․ 을

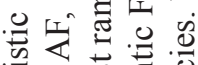

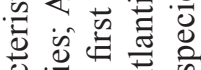

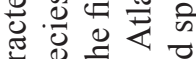

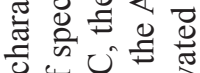

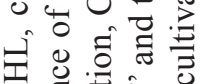
Uี हैं

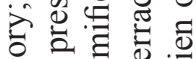
品 ब

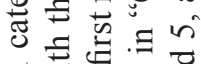

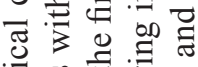
कo थ

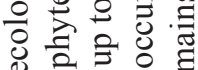

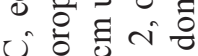

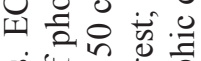
ये फै ठั. की

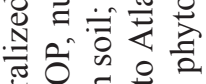
志

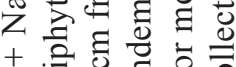
+ . द्वे चे के

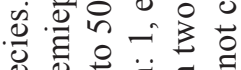

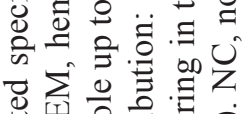
牙完宗

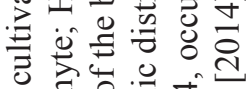
0. .

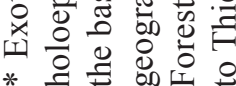


Table 4. Comparison between studies regarding vascular epiphytes conducted in areas of Seasonal Semideciduous Forest in the Atlantic Forest.

\begin{tabular}{lccccccc}
\hline Locality & State & Vegetation & NP & NS & H' & J & Source \\
\hline Campo Mourão & PR & SSF, MOF & 80 & 43 & 3,17 & 0,86 & Geraldino et al. (2010) \\
Krambeck & MG & SSF & 61 & 47 & 2,95 & 0,77 & Present study \\
Ouro Preto & MG & SSF & 231 & 35 & 2,77 & - & Ferreira (2011) \\
Erechim (borda) & RS & SSF, MOF & 228 & 20 & 2,38 & 0,78 & Bernardi \& Budke (2010) \\
Erechim (interior) & RS & SSF, MOF & 271 & 20 & 2,27 & 0,75 & \\
FloNa de Ipanema & SP & SSF & 270 & 21 & 2,27 & 0,71 & Bataghin et al. (2010) \\
Ivinhema & MS & SSF & 199 & 24 & 2,24 & 0,71 & Tomazini (2007) \\
Maringá & PR & SSF & 90 & 21 & 1,11 & 0,82 & Dettke et al. (2008) \\
\hline
\end{tabular}

FloNa - National Forest. State - MG: Minas Gerais; MS: Mato Grosso do Sul; PR: Paraná; RS: Rio Grande do Sul; SP: São Paulo. Vegetation: SSF - Seasonal Semidecidual Forest; MOF - Mixed Ombrophilous Forest. NP: number of phorophytes. NS: number of species. H': Shannon diversity index. P: Pielou evenness index.
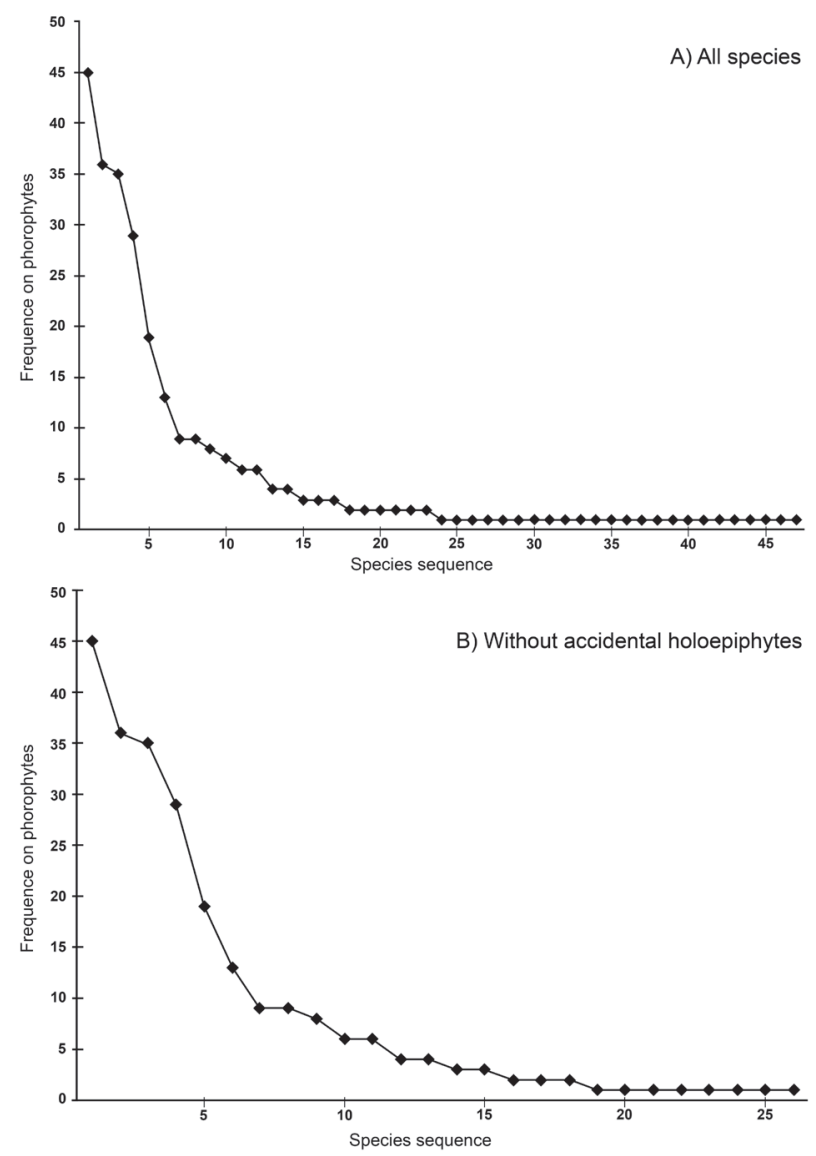

Figure 2. Species sequences from most common to rarest, expressed as the number of absolute occurrences in the 61 sampled phorophytes.

Bromeliaceae and Polypodiaceae (Dislich \& Mantovani 1998, Fabricante et al. 2006, Dettke et al. 2008, Bataghin et al. 2010, Furtado \& Menini Neto 2015). This pattern has also been observed in studies conducted by Werner \& Gradstein (2009) when analysing gradients of environmental disturbance in the Andes. Two main reasons could explain this pattern: several species of ornamental interest had been collected and/or those species that cannot tolerate the environmental changes had disappeared. Also, fragmentation could be responsible for this result since edge effects often influence the richness and abundance of species, leading to changes in community composition (Bierregaard et al. 1992, Metzger 1999).

In addition, a natural reduction in the proportion of occurrence of Orchidaceae compared to other families in SSFs of the Atlantic domain (Kersten 2010) could also be responsible for the observed configuration. This possibility is corroborated by Menini Neto et al. (2009a) who showed that the Bromeliaceae and Araceae are richer than the Orchidaceae in an area of SSF with reduced anthropogenic disturbance. However, the limited knowledge about vascular epiphytes in seasonal semi-deciduous forests impedes further conclusions.

Richness of the Polypodiaceae and Bromeliaceae both in MK and in other aforementioned studies is essentially due to the representation of Microgramma and Pleopeltis (in the first family) and Tillandsia (in the second family), whose species often occur in a wide range of environments, both in primary forests and urban centres. Regarding this subject, we must highlight the species of Tillandsia, known as biomonitors of air quality, due to their high tolerance to pollution in urban areas (Graciano et al. 2003, Alves et al. 2008, Bermudez et al. 2009). Thus, changes resulting from anthropogenic disturbances, such as 
increases in luminosity and temperature, reduction of humidity, scarcity of pollinators and pollution, can act as environmental filters, turning the occurrence of species that cannot tolerate such changes and opening space for the establishment and proliferation of other

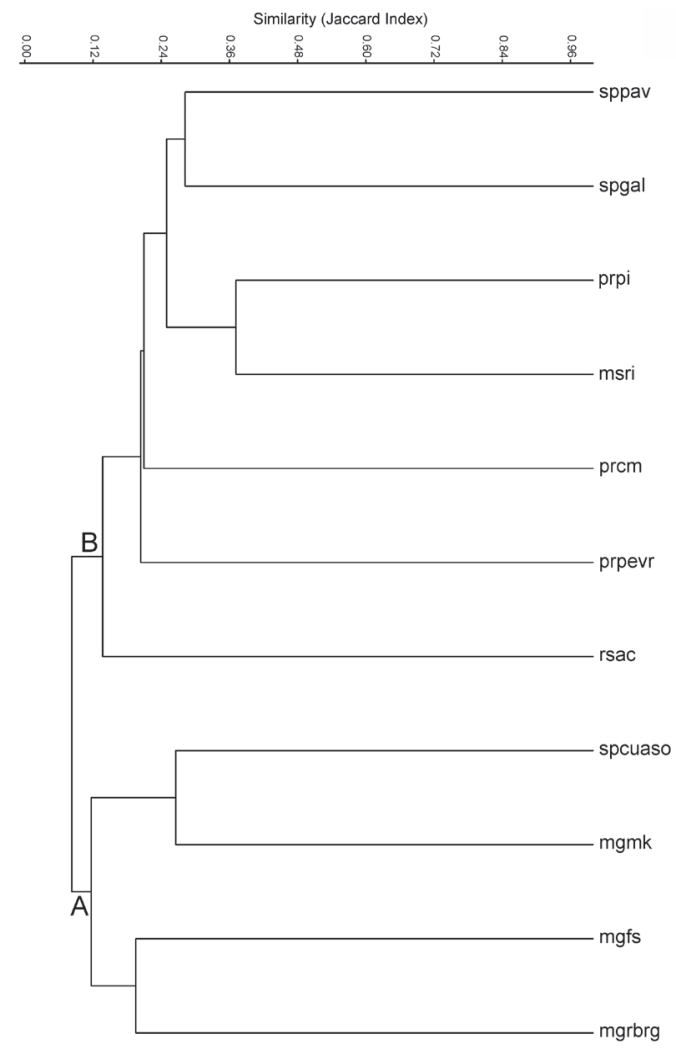

Figure 3. Dendrogram (Jaccard index) obtained from the cluster analysis of 238 species and 11 areas of seasonal forests of Brazil. Cophenetic correlation $=0.91$. Acronyms according to table 1 . species in such environments, including accidental holoepiphytes, due to reduced competition.

The wide distribution of several species and the presence of exotic species point to a flora adapted to several natural environments as well as to disturbed urban environments. Changes caused by degradation of the environment also result from the predominance of accidental epiphytes, resulting in disequilibrium of the epiphytic community due to the reduction of competition with specialist species, such as the characteristic holoepiphytes (Barthlott et al. 2001, Bataghin et al. 2008, Dettke et al. 2008, Furtado \& Menini Neto 2015). Such disturbance is the reason of the occurrence of typically terricolous species as epiphytic species, and that act as pioneer species in the epiphytic synusia, both in terms of exotics (Drymaria cordata, Impatiens walleriana, Tradescantia zebrina) and natives (Ageratum fastigiatum, Emilia sonchifolia, Thelypteris dentata, Urera baccifera). Some of these genera/species have already been recorded as accidental holoepiphytes in disturbed environments, reinforcing this possibility (Holzner \& Numata 1982, Bhatt et al. 2015, Furtado \& Menini Neto 2015).

Diversity and ecology - Richness and diversity values $\left(H^{\prime}=2.95\right)$ were greater than expected when compared with other studies in areas of seasonal semi-deciduous forest and ecotones between this formation and mixed ombrophilous forests in the Atlantic domain. Even if accidental holoepiphytes were removed from the analysis, the MK would lose only one position in the rank and would still be among the three richest areas (with 26 species). The other three compared areas

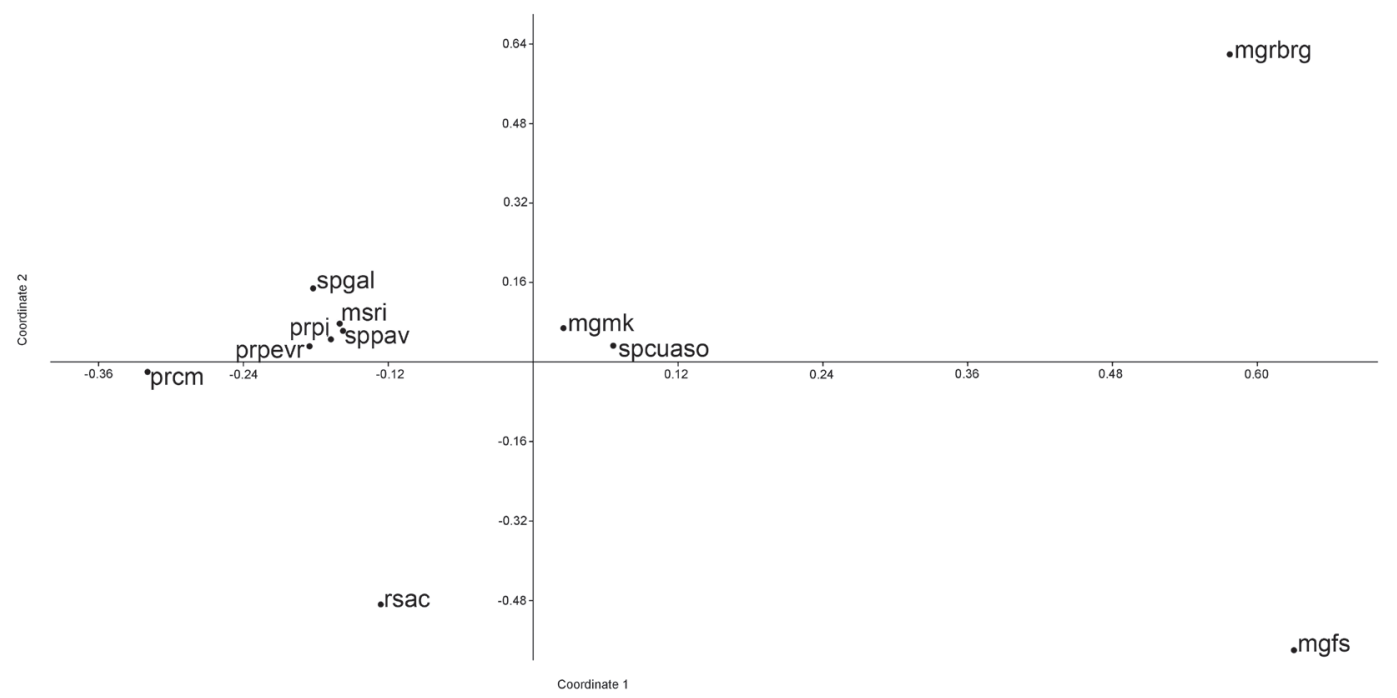

Figure 4. Principal coordinates analysis of 238 species and 11 areas of seasonal forests of Brazil. Acronyms according to table 1. 
were characterised by low anthropogenic disturbances and one of them, Campo Mourão, is an ecotone area, which is often richer due to the presence of aggregate species of both formations (in some cases, involving seasonal semi-deciduous and mixed ombrophilous forests) (Geraldino et al. 2010). Thus, the richness and diversity of MK must be considered high, despite the degradation of its vegetation and relatively low number of sampled phorophytes. The proximity of a water body in the MK could be responsible for this, as humidity is one of the main features affecting the occurrence of epiphytes (Gentry \& Dodson 1987, Benzing 1990, Barthlott et al. 2001) and, in general, this humidity is reduced in the seasonal forests (Oliveira-Filho et al. 2006). In addition, the forest fragment of the MK environmental protection area, which has been regenerating for the past 70 years, can be a source of epiphytic species for the studied area, enriching its composition despite intense anthropogenic activity.

However, the Pielou index $(J=0.77)$ revealed a relatively low evenness of the community, which is related to the higher frequency of a few species, while several species had just a few occurrences in the sampled area. Hietz (1999) and Bataghin et al. (2010) also found similar configuration in environments with different types of disturbances. Particularly, the structure of frequency distribution found in MK was similar to that observed by Hietz (1999) in an alder crop, showing a reduced number of dominant species, few species with intermediary frequencies and several rare species. Such configurations must have been caused by anthropogenic activity or even edge effects, since both of these effects are responsible for the reduction of population sizes (Terborgh 1992). In addition, some groups of epiphytes are less tolerant to environmental variations generated by disturbances (Sota 1971).

An analysis of the five most frequent species on phorophytes showed a similar composition of genera between MK and seven other areas composed of seasonal semi-deciduous forest. Some genera must be highlighted: Microgramma and Pleopeltis (Polypodiaceae) (found in five and four areas, respectively) and Tillandsia (Bromeliaceae) (four areas) and, to a lesser degree, Billbergia (Bromeliaceae) (found in two other areas). Conversely, species composition was quite distinct and only Microgramma squamulosa and Tillandsia stricta were shared between three and two areas, respectively. 
Table 6. Conventional and taxonomic diversity indices of the vascular epiphytes in four strata in Mata do Krambeck.

\begin{tabular}{|c|c|c|c|c|c|c|}
\hline \multirow{2}{*}{ Indices } & \multirow{2}{*}{ Expected value } & \multicolumn{4}{|c|}{ Strata } & \multirow{2}{*}{$\begin{array}{c}\text { Levels of } \\
\text { significance }\end{array}$} \\
\hline & & A & $\mathrm{B}$ & $\mathrm{C}$ & $\mathrm{D}$ & \\
\hline $\mathrm{S}$ & - & $21(11)$ & $29(18)$ & $23(17)$ & $20(19)$ & - \\
\hline$H^{\prime}$ & - & $2.75^{\mathrm{A}}$ & $2.73^{\mathrm{Ab}}$ & $2.29^{\mathrm{abC}}$ & $2.44^{\mathrm{aBC}}$ & 0.05 \\
\hline$J$ & - & 0.90 & 0.81 & 0.73 & 0.81 & - \\
\hline$\Delta$ & 72.35 & 68.47 & 68.41 & 64.40 & 68.71 & 0.05 \\
\hline$\Delta^{*}$ & 67.96 & 76.40 & 76.47 & 76.25 & 77.22 & 0.05 \\
\hline$\Delta^{+}$ & 79.64 & 80.01 & 79.23 & 78.62 & 77.64 & 0.05 \\
\hline$\Lambda^{+}$ & - & 545.51 & 623.04 & 624.16 & 619.79 & - \\
\hline
\end{tabular}

$\mathrm{S}$, number of species. Between parentheses are the numbers of species excluding accidental holoepiphytes. $H^{\prime}$, Shannon diversity index; $J$, Pielou's evenness index; $\Delta$, taxonomic distinctness; $\Delta^{*}$, taxonomic diversity $\Delta^{+}$, average taxonomic distinctness; and $\Lambda^{+}$, variation in taxonomic distinctness. In the Shannon index, same upper-case letters represent non-significant differences, and same lower-case letters represent significant differences between the values. Strata: A, from the base of the bole up to $50 \mathrm{~cm}$ from soil; $\mathrm{B}$, from $50 \mathrm{~cm}$ up to the first ramification, $\mathrm{C}$, the first ramification of the crown; D, the rest of the crown.

Vertical stratification along the phorophytes resulted in lower values of $H^{\prime}(2.29)$ and $J(0.73)$ for internal crown. Our results showed more unevenness in the distribution of occurrences (here used in substitution to abundance) compared to other strata, since only five species (out of 23) were dominant and occurred more than 10 times in such strata, while the other species were recorded less than four times. The lower values of $\Delta(64.40)$ and $\Delta^{*}$ (76.25) showed similar results for internal crown, although they were not significantly different from the expected values $(p>0.05)$. The higher value of $\Lambda+$ (624.19) demonstrated strong unevenness in the frequency of taxa, since only two families (among nine recorded in the internal crown) and five genera (among 16) exhibited more than two occurrences (Billbergia, Portea, and Tillandsia in Bromeliaceae and Microgramma and Pleopeltis in Polypodiaceae).

It is likely that there were no microhabitats, because the surveyed trees were isolated (without a closed canopy) and near a water body. Thus, there were most probably no differences in light availability and humidity between the base and top of the phorophytes. We therefore assume that the inexistence of a typical stratification can be associated with the pressure of collections in the base and trunk top strata, mainly concerning the Bromeliaceae species (such as the ornamentals P. petropolitana and Billbergia horrida), which were more representative in the internal and external crown strata (strata C and D, respectively), despite the large sizes of these plants. This possibility is supported by the fact that the Orchidaceae recorded in the analysed trees were concentrated in the external crown, whose populations already may have been reduced due to extraction in the area.

The characteristic holoepiphyte fern species were distributed more or less similarly across all strata (trunk base, three species; trunk top, seven species; internal crown, five species; external crown, five species). These results are different from those noted by Benzing (1990), who cited studies conducted in South America, Asia and Oceania, which stated that ferns typically were concentrated in the inferior levels of the phorophytes. However, some species of ferns could tolerate higher exposure to sunlight and/or seasonal dry environments, allowing their occurrence in superior strata. In MK, we recorded three species of Pleopeltis that exhibited poikilohydric features, such as strong rolling of the fronds during dry periods and tolerance to desiccation. Another two species belonged to Microgramma, a genus whose species have thick cuticles and suberified stems with water storage to avoid desiccation, as noted by Dubuisson et al. (2009). 
Another observed pattern was the concentration of accidental holoepiphytes on the base and top trunk strata. This was an expected result, since the phorophyte base, nearer the soil, allows the development of species that lack adaptation to epiphytic environments due to higher humidity and, in many cases, the accumulation of organic matter. In addition, according to Benzing (1990), accidental holoepiphytes are commonly found in the humid forest, and although the MK is not a humid forest, the close proximity to a lake can contribute to these occurrences. Even the plants that occurred in the trunk top were nearer the trunk base than the crown.

By removing the accidental holoepiphytes and analysing the composition of other categories along the phorophyte, it is possible to notice that richness of the strata was similar (trunk top, 18; internal crown, 17; and external crown, 19), although with strong reduction in the richness of the trunk base (21 reduced to 11). However, the occurrences by strata with higher concentrations in the crown maintained this configuration (trunk base, 35; trunk top, 87; internal crown, 110; and external crown, 166). This proportion of occurrence (trunk base, $8.7 \%$; trunk top, $21.85 \%$; internal crown, $27.6 \%$; and external crown, $41.7 \%$ ) was, to a certain extent, similar to that observed by Johansson (1975) for epiphytic orchids; however, in this study, the percentage of trunk base was higher and that of external crown was lower. Thus, anthropogenic disturbances can be responsible for the strong change in composition and proportion of occurrence also in the epiphytic synusia, which is commonly observed in other groups (Mckinney 2008).

Similarity - Cluster analysis showed a clear longitudinal gradient, suggesting the influence of the distance to the ocean on the floristic relationships between the areas. Group A was composed of two areas whose distance to the ocean varied from $60 \mathrm{~km}$ ("spcuaso") to $165 \mathrm{~km}$ ("mgrbrg"), isolating it from group B (whose area with the closest proximity to the ocean was about $250 \mathrm{~km}$ away from it), located in the transition with the Cerrado. Forzza et al. (2014) found a similar gradient when comparing the vascular flora of the Reserva Biológica da Represa do Grama ("mgrbrg") with nine other areas of the southeastern region of Brazil, with strong segregation between littoral and inland areas.

Although the areas of Minas Gerais are composed of SSF, the influence of dense ombrophilous forest has been noted by Barbosa et al. (2014) in "mgfs" and by Forzza et al. (2014) in "mgrbrg". Pifano et al.
(2007) also noticed such influence on the composition of the phanerogamic flora of Morro do Imperador, an area about $4 \mathrm{~km}$ from $\mathrm{MK}$, and stated that milder temperatures of the region and geographic proximity to the littoral could be responsible for this relationship. Despite the geographic distance (between 400-460 km), the three areas of Minas Gerais were grouped together with "spcuaso" (in São Paulo), which is composed of dense ombrophilous and seasonal semi-deciduous forests (Dislich \& Mantovani 1998), corroborating the influence of the first forest formation on its flora composition. The existence of water bodies associated with all areas of Minas Gerais could also collaborate through the establishment of plants typically found in ombrophilous environments, which could not tolerate the seasonality of semi-deciduous forests, influencing such observed relationships. The internal relationships of group B demonstrated a latitudinal gradient with initial segregation of the southernmost area ("rsac"), subsequent merging of two areas with similar latitude ("prpevr" and "prcm") and formation of two other groups with closer latitudes (one composed of "prpi" and "msri" and another of "sppav" and "spgal"). Since the altitudes between the areas did not exhibit marked differences, it is likely that latitude influenced temperature, agreeing with what has been observed by Oliveira-Filho et al. (2006) regarding tree species in seasonal forests and, consequently, composition of species and similarity between the areas.

The PCoA corroborated the initial separation between the two groups (A and B), with a strong species turnover related to longitudinal gradient, although the latitudinal gradient observed in group B was not confirmed. The separation of "mgrbrg" and "mgfs" from the other areas was due to the richness of both areas (69 and 78 species, respectively), also reflecting the higher degree of conservation compared to the other areas of group A ("mgmk" and "spcuaso"), which are both located in an urban environment, subject to strong anthropogenic pressure and less species-rich ( 24 and 40 species, respectively).

\section{Conclusions}

This study presented the characterisation of the vascular epiphyte community in an urban forest environment, correlated it with environmental and geographical factors and compared it with similar studies conducted in Neotropical Region, seeking to evaluate the possible existence of a pattern in the structure of such a community in an anthropogenic environment. 
In this sense, the observed proportion of ecological categories uncovered an enhancement of accidental holoepiphytes in a disturbed environment. The accidental holoepiphytes constituting the richest ecological category is unprecedented. However, this category has apparently been neglected in similar studies, even ignored several times. Regarding an environment undergoing regeneration, it is possible that the ecological role of accidental holoepiphytes is underestimated, as their occurrence could be important in the initial composition of the epiphytic flora, preparing the environment to the subsequent establishment of the specialists (i.e., the characteristic holoepiphytes). More studies will need to be conducted to evaluate this possibility.

We observed some congruence in the composition of families and genera among the most frequent ecological studies conducted in the Atlantic domain. However, in a specific level, this composition was relatively distinct according to the locality, despite the prominence of $M$. squamulosa and T. stricta.

Taking into account the conditions of the environment and relatively small numbers of phorophytes sampled, the richness and diversity found in MK are impressive. However, if the anthropogenic disturbance does not cease, the number of rare species could decline due to local extinction, enhancing the dominance of a few taxa and reducing the diversity. Conversely, if the community continues to regenerate, the rare species can enhance their frequencies, compete with the most common species as well as with the accidental holoepiphytes, reduce their occurrence and establish a balance in the community. However, the importance of the occurrence of other components of the ecosystem, such as pollinators and dispersers, must be taken into consideration.

Therefore, it is important to encourage long-duration studies with epiphytic synusia in order to clarify how these changes occur in the communities located in urban environments in a temporal dynamic system.

\section{Acknowledgments}

We wish to thank the Pró-reitoria de Pesquisa of the Universidade Federal Juiz de Fora for the license to conduct this study and Dr. Vinícius Dittrich for the identification of the ferns.

\section{Literature cited}

Alves, E.S., Moura, B.B. \& Domingos, M. 2008. Structural analysis of Tillandsia usneoides L., exposed to air pollutants in São Paulo city - Brazil. Water Air Soil Pollution 189: 61-68.
Alves, F.E. \& Menini Neto, L. 2014. Vascular epiphytes in a forest fragment of Serra da Mantiqueira and floristic relationships with Atlantic high altitude areas in Minas Gerais. Brazilian Journal of Botany 37: 187-196.

Alves, M.E.O., Brun, C., Dal Forno, R.S. \& Essi, L. 2014. Levantamento de espécies epífitas vasculares da zona urbana do município de Palmeira das Missões, RS, Brasil. Ciência e Natura 36: 268-276.

Arévalo, R. \& Betancur, J. 2004. Diversidad de epífitas vasculares en cuatro bosques del sector suroriental de la Serranía de Chiribiquete, Guayana Colombiana. Caldasia 26: 359-380.

Barbosa, D.E.F. Basílio, G.A., Silva F.R. \& Menini Neto, L. 2014. Vascular epiphytes in a remnant of seasonal semideciduous forest in Zona da Mata of Minas Gerais, Brazil. Bioscience Journal 31: 623-633.

Barthlott, W., Schmit-Neuerburg, V., Nieder, J. \& Engwald, S. 2001. Diversity and abundance of vascular epiphytes: a comparison of secondary vegetation and primary montane rain forest in the Venezuelan Andes. Plant Ecology 152: 145-156.

Bataghin, F.A., Fiori, A. \& Toppa, R.H. 2008. Efeito de borda sobre epífitos vasculares em floresta ombrófila mista, Rio Grande do Sul, Brasil. O Mundo da Saúde 32: 329-338.

Bataghin, F.A., Barros, F. \& Pires, J.S.R. 2010. Distribuição da comunidade de epífitas em sítios sob diferentes graus de perturbação na Floresta Nacional de Ipanema, Brasil. Revista Brasileira de Botânica 33: 501-512.

Becker, D.F.P., Padoin, T.O.H., Nascimento, C.A., Robalski, J.L., Linden, R. \& Schmitt, J.L. 2015. Riqueza e composição de epífitos vasculares em áreas urbanas da Bacia Hidrográfica do Rio dos Sinos, RS, Brasil. Pesquisas, Botânica 68: 227-238.

Benzing, D.H. 1990. Vascular epiphytes: general biology and related biota. Cambridge University Press, Cambridge.

Bermudez, G.M.A., Rodriguez, J.H. \& Pignata, M.L. 2009. Comparison of the air pollution biomonitoring ability of three Tillandsia species and the lichen Ramalina celastri in Argentina. Environmental Research 109: 6-14.

Bernardi, S. \& Budke, J.C. 2010. Estrutura da sinúsia epifítica e efeito de borda em uma área de transição entre Floresta Estacional Semidecídua e Floresta Ombrófila Mista. Floresta 40: 81-92.

BFG - Brazil Flora Group. 2015. Growing knowledge: an overview of Seed Plant diversity in Brazil. Rodriguésia 66: 1085-1113.

Bhatt, A., Gairola, S., Govender, Y., Baijnath, H. \& Ramdhani, S. 2015. Epiphyte diversity on host trees in an urban environment, eThekwini Municipal Area, South Africa. New Zealand Journal of Botany 53: 24-37. 
Bianchi, J.S., Bento, C.M. \& Kersten, R.A. 2012. Epífitas vasculares de uma área de ecótono entre as Florestas Ombrófilas Densa e Mista, no Parque Estadual do Marumbi, PR. Estudos de Biologia 34: 37-44.

Biedinger, N. \& Fischer, E. 1996. Epiphytic vegetation and ecology in Central African forests (Rwanda, Zaïre). Ecotropica 2: 121-142.

Bierregaard J.R., R.O., Lovejoy, T.E., Kapos, V., Santos, A.A. \& Hutchings, R.W. 1992. The biological dynamics of tropical rainforest fragments. BioScience 412: 859-866.

Biral, L. \& Lombardi, J.A. 2012. Flora vascular da Mata da Pavuna, Botucatu, SP, Brasil. Rodriguésia 63: 441-450.

Bolund, P. \& Hunhamma, S. 1999. Ecosystem services in urban areas. Ecological Economics 29: 293-301.

Bonametti, J.H. 2003. Arborização urbana. Revista Terra e cultura: Cadernos de ensino e pesquisa 36: 51-55.

Borgo, M., Silva, S.M. \& Petean, M.P. 2002. Epífitos vasculares em um remanescente de floresta estacional semidecidual, município de Fênix, PR, Brasil. Acta Biologica Leopoldensia 24: 121-130.

Breier, T.B. 2005. O epifitismo vascular em florestas do Sudeste do Brasil. Tese de Doutorado, Universidade Estadual de Campinas, Campinas.

Bussmann, R.W. 2001. Epiphyte diversity in a tropical Andean forest - Reserva Biológica San Francisco, Zamora-Chinchipe, Ecuador. Ecotropica 7: 43-49.

Catling, P.M. \& Lefkovitch, L.P. 1989. Associations of vascular epiphytes in a Guatemalan cloud Forest. Biotropica 21: 35-40.

Ceja-Romero, J., Mendoza-Ruiz, A., López-Ferrari, A.R., Espejo-Serna, A., Pérez-Garcia, B. \& GarcíaCruz, J. 2010. Las epífitas vasculares del estado de Hidalgo, México: diversidad y distribución. Acta Botanica Mexicana 93: 1-39.

Cervi, A.C. \& Borgo, M. 2007. Epífitos Vasculares no Parque Nacional do Iguaçu, Paraná (Brasil). Levantamento Preliminar. Fontqueria 55: 415-422.

Clarke, R.K. \& Warwick, R.M. 1998. A taxonomic distinctness index and its statistical properties. Journal of Applied Ecology 35: 523-531.

Clarke, R.K. \& Warwick, R.M. 2001. A further biodiversity index applicable to species lists: variation in taxonomic distinctness. Marine Ecology Progress Series 216: 265-278.

Dettke, G.A., Orfrini, A.C \& Milaneze-Gutierre, M.A. 2008. Composição e distribuição de epífitas vasculares em um remanescente alterado de Floresta Estacional Semidecidual no Paraná, Brasil. Rodriguésia 59: 859-872.

Dislich, R. \& Mantovani, W. 1998. A Flora de epífitas vasculares da Reserva da Cidade Universitária "Armando de Salles Oliveira" (São Paulo, Brasil). Boletim de Botânica da Universidade de São Paulo 17: 61-83.
Dittrich, V.A.O., Kozera, C. \& Silva, S.M. 1999. Levantamento florístico dos epífitos vasculares do Parque Barigüi, Curitiba, Paraná, Brasil. Iheringia, série Botânica 52: 11-22.

Drummond, G.M., Martins, C.S., Machado, A.B.M., Sebaio, F.A. \& Antonini, Y. (orgs.). 2005. Biodiversidade em Minas Gerais: um atlas para sua conservação. 2 ed. Fundação Biodiversitas, Belo Horizonte.

Dubuisson, J.Y., Scheider, H. \& Hennequin, S. 2009. Epiphytism in ferns: diversity and history. Comptes Rendus Biologies 332: 120-128.

Fabricante, J.R., Andrade, L.A. \& Marques, F.J. 2006. Componente epifítico vascular ocorrente em árvores urbanas. Cerne 12: 399-405.

Ferreira, M.T.M. 2011. Composição florística e distribuição vertical de epífitas vasculares sobre indivíduos de Guapira opposita (Vell.) Reitz (Nyctaginaceae) em um fragmento florestal na Serra da Brígida, Ouro Preto, MG. Dissertação de Mestrado, Universidade Federal de Ouro Preto, Ouro Preto.

Fonseca, C.R. \& Carvalho, F.A. 2012. Aspectos florísticos e fitossociológicos da comunidade arbórea de um fragmento urbano de Floresta Atlântica (Juiz de Fora, MG, Brasil. Bioscience Journal 28: 820-832.

Forzza, R.C., Pifano, D.S., Oliveira-Filho, A.T., Meireles, L.D., Faria, P.L., Salimena, F.R., Mynssen, C.M. \& Prado, J. 2014. Flora vascular da Reserva Biológica da Represa do Grama, Minas Gerais, e sua relação florística com outras florestas do sudeste brasileiro. Rodriguésia 65: 275-292.

Freitas, L., Salino, A., Menini Neto, L., Almeida, T.E., Mortara, S.R., Stehmann, J.R., Amorim, A.M., Guimarães, E.F., Coelho, M.N., Zanin, A., Forzza, R.C. 2016. A comprehensive checklist of vascular epiphytes of the Atlantic Forest reveals outstanding endemic rates. PhytoKeys 58: 65-79.

Furtado, S.G. \& Menini Neto, L. 2015. Diversity of vascular epiphytes in urban environment: a case study in a biodiversity hotspot, the Brazilian Atlantic Forest. CES Revista 29: 82-101.

Gentry, A.H. \& Dodson, C.H. 1987. Diversity and biogeography of neotropical vascular epiphytes. Annals of the Missouri Botanical Garden 74: 205-223.

Geraldino, H.C.L., Caxambú, M.G., Souza, D.C. 2010. Composição florística e estrutura da comunidade de epífitas vasculares em uma área de ecótono em Campo Mourão, PR, Brasil. Acta botanica brasilica 24: 469-482.

Giongo, C. \& Waechter, J.L. 2004. Composição florística e estrutura comunitária de epífitos em uma floresta de galeria na Depressão Central do Rio Grande do Sul. Revista Brasileira de Botânica 27: 563-572.

Gonçalves, C.N. \& Waechter, J.L. 2003. Aspectos florísticos e ecológicos de epífitos vasculares sobre figueiras isoladas no norte da planície costeira do Rio Grande do Sul. Acta botanica brasilica 17: 89-100. 
Graciano, C., Fernandéz, L.V. \& Caldiz, D.O. 2003. Tillandsia recurvata $\mathrm{L}$. as a bioindicator of sulfur atmospheric pollution. Ecología Austral 13: 3-14.

Groppo, M. \& Pirani, J.R. 2005. Levantamento floristico das espécies de ervas, subarbustos, lianas e hemiepífitas da mata da Reserva da Cidade Universitária "Armando de Salles Oliveira”, São Paulo, SP, Brasil. Boletim de Botânica da Universidade de São Paulo 23: 141-233.

Hammer, Ø., Harper, D.A.T \& Ryan, P.D. 2001. Paleontological Statistics software package for education and data analysis. Palaeontologia Electronica 4: 1-9.

Hefler, S.M. \& Faustioni, P. 2004. Levantamento florístico de epífitos vasculares do Bosque São Cristovão Curitiba - Paraná - Brasil. Revista Estudos de Biologia 26: 11-19.

Hietz, P. 1999. Diversity and conservation of epiphytes in a changing environment. International conference on biodiversity and bioresources: conservation and utilization. Phuket, Thailand. Available in http://www. iupac.org/symposia/proceedings/phuket97/hietz.html (access in 03-VI-2014).

Hietz, P. \& Hietz-Seifert, U. 1995. Composition and ecology of vascular epiphyte communities along an altitudinal gradient in Central Veracruz, Mexico. Journal of Vegetation Science 6: 487-498.

Holzner, W. \& Numata, M. 1982. Biology and ecology of weeds. The Hague, Dr. W. Junk Publishers.

Johansson, D.R. 1974. Ecology of vascular epiphytes in West African rain forest. Acta Phytogeographica Suecica 59: 1-136.

Johansson, D.R. 1975. Ecology of epiphytic orchids in West African rain forests. American Orchid Society Bulletin 44: 125-136.

Kersten, R.A. 2010. Epífitas vasculares - Histórico, participação taxonômica e aspectos relevantes, com ênfase na Mata Atlântica. Hoehnea 37: 9-38.

Kersten, R.A. \& Silva, S.M. 2001. Composição florística e distribuição espacial de epífitas vasculares em floresta da planície litorânea da Ilha do Mel, Paraná, Brasil. Revista Brasileira de Botânica 24: 213-226.

Kersten, R.A., Kuniyoshi, Y.S. \& Roderjan, C.V. 2009 Epífitas vasculares em duas formações ribeirinhas adjacentes na bacia do rio Iguaçu - Terceiro Planalto Paranaense. Iheringia, Série Botânica 64: 33-43.

Linares, E.L. 1999. Diversidad y distribución de las epífitas vasculares en un gradiente altitudinal en San Francisco, Cundinamarca. Revista da Academia Colombiana de Ciências 33: 133-139.

Madison, M. 1977. Vascular epiphytes: their systematic occurrence and salient features. Selbyana 2: 1-13.

Marris, E. 2009. Ragamuffin Earth. Nature 460: 450-453.

Mckinney, M.L. 2006. Urbanization as a major cause of biotic homogenization. Biological Conservation 127: 247-260.
Mckinney, M.L. 2008. Effects of urbanization on species richness: a review of plants and animals. Urban Ecosystems 11: 161-176.

Menini Neto, L., Forzza, R.C. \& Zappi, D. 2009a. Angiosperm epiphytes as conservation indicators in forest fragments, a case study from southeastern Minas Gerais, Brazil. Biodiversity and Conservation 18: 3785-3807.

Menini Neto, L., Matozinhos, C.N., Abreu, N.L., Valente, A.S.M., Antunes, K., Souza, F.S., Viana, P.L. \& Salimena, F.R.G. 2009b. Flora vascular não-arbórea de uma floresta de grota na Serra da Mantiqueira, Zona da Mata de Minas Gerais, Brasil. Biota Neotropica 9: $149-161$

Metzger, J.P. 1999. Estrutura da paisagem e fragmentação: análise bibliográfica. Anais da Academia Brasileira de Ciências 71: 445-463.

Myers, N., Mittermeier, R.A., Mittermeier, C.G., Fonseca, G.A.B. \& Kent, J. 2000. Biodiversity hotspots for conservation priorities. Nature 403: 853-858.

Oliveira, L.C., Padilha, P.T., Dalmolin, E.B., Azeredo, T.E.V. \& Citadini-Zanette, V. 2013. Componente epifítico vascular de um fragmento florestal urbano, município de Criciúma, Santa Catarina, Brasil. Biotemas 26: 33-44.

Oliveira-Filho, A.T., Jarenkow, J.A. \& Rodal, M.J.N. 2006. Floristic relationships of seasonally dry forests of eastern South America based on tree species distributions patterns. In: R.T. Pennington, J.A. Ratter, \& G.P. Lewis (eds.). Neotropical savannas and dry forests: Plant diversity, biogeography and conservation. The Systematics Association Special volume Series 69, CRC Press - Taylor and Francis Group, Boca Raton, Florida, pp. 159-192.

Pifano, D.S., Valente, A.S.M., Castro, Pivari, M.O.D., Salimena, F.R.G, Oliveira-Filho, A.T. 2007. Similaridade entre os habitats da vegetação do Morro do Imperador, Juiz de Fora, Minas Gerais, com base na composição de sua flora fanerogâmica. Rodriguésia 58: 885-904.

R Core Team. 2014. R: A language and environment for statistical computing. R Foundation for Statistical Computing, Vienna, Austria. Available in http://www.Rproject.org/ (access in 05-IV-2014).

Ricklefs, R.E. 2011. A economia da natureza. 6 ed. Guanabara Koogan, Rio de Janeiro.

Rogalski, J.M. \& Zanin, E.M. 2003. Composição florística de epífitos vasculares no estreito de Augusto César, Floresta Estacional Decidual do Rio Uruguai, RS, Brasil. Revista Brasileira de Botânica 26: 551-556.

Schütz-Gatti, A.L. 2000. O componente epifítico vascular na Reserva Natural de Salto Morato, Guaraqueçaba PR. Dissertação de Mestrado, Universidade Federal do Paraná, Curitiba. 
Sota, E.R. 1971. El epifitismo y las pteridofitas en Costa Rica (America Central). Nova Hedwigia 21: 401-465.

Terborgh, J. 1992. Maintenance of diversity of tropical forests. Biotropica 24: 283-292.

Thiers, B. 2016 [continuously updated]. Index Herbariorum: A global directory of public herbaria and associated staff. New York Botanical Garden's Virtual Herbarium. Available in http://sweetgum.nybg.org/ih/ (access in 04-VI-2016).

Tomazini, V. 2007. Estrutura de epífitas vasculares e de forófitos em formação florestal ripária do Parque Estadual do Rio Ivinhema, Estado de Mato Grosso do Sul, Brasil. Tese de Doutorado, Universidade Estadual de Maringá, Maringá.
Veloso, H.P., Rangel Filho, A.L.R. \& Lima, J.C.A. 1991. Classificação da vegetação brasileira, adaptada a um sistema universal. Instituto Brasileiro de Geografia e Estatística, Rio de Janeiro.

Waechter, J.L. 1992. O epifitismo vascular na planície costeira do Rio Grande do Sul. Tese de Doutorado, Universidade Federal de São Carlos, São Carlos.

Werner, F. \& Gradstein, S.R. 2009. Diversity of dry forest epiphytes along a gradient of human disturbance in the tropical Andes. Journal of Vegetation Science 20: 59-68.

Zotz, G. 2013. The systematic distribution of vascular epiphytes - a critical update. Botanical Journal of the Linnean Society 171: 453-481. 